\title{
Paideusis
}

\section{Newman on Christianity and Medical Science}

\section{Jay Newman}

Volume 3, Number 2, 1990

URI: https://id.erudit.org/iderudit/1073398ar

DOI: https://doi.org/10.7202/1073398ar

See table of contents

Publisher(s)

Canadian Philosophy of Education Society

ISSN

0838-4517 (print)

1916-0348 (digital)

Explore this journal

Cite this article

Newman, J. (1990). Newman on Christianity and Medical Science. Paideusis, 3(2), 28-35. https://doi.org/10.7202/1073398ar

This document is protected by copyright law. Use of the services of Erudit (including reproduction) is subject to its terms and conditions, which can be viewed online.

https://apropos.erudit.org/en/users/policy-on-use/
This article is disseminated and preserved by Érudit.

Érudit is a non-profit inter-university consortium of the Université de Montréal, Université Laval, and the Université du Québec à Montréal. Its mission is to promote and disseminate research.

https://www.erudit.org/en/ 


\title{
Newman on Christianity and Medical Science
}

\author{
Jay Newman \\ University of Guelph
}

Much has been written about how the Irish bishops invited the dynamic Oxford-educated convert, John H. Newman, to found a Catholic University, and how Newman, in accepting that invitation, embarked upon one of the most disappointing of the numerous ill-fated ventures of his controversial career. But the project was far from fruitless, for it resulted in at least two notable achievements: the writing of what we know today as The Idea of a University and the establishment of an Irish medical school. Newman's address to the medical students on "Christianity and Medical Science" is now the last "chapter" of The Idea of a University and one of the least well known, and it is apt to strike many contemporary readers as dogmatic, contrived, quite dated, and of little contemporary relevance. Yet, in this short piece, Newman discusses issues that are still being hotly debated and, with characteristic vigour, he advances views that are still widely held.

Newman knew little about medicine, but in his address he indicates to his audience of medical students that the subject of his address, "as you may conceive, is often before my own mind: I mean, the exact relation in which your noble profession stands towards the Catholic University itself and towards Catholicism generally" (505). ${ }^{1}$ Newman goes on to discuss "the principal duty of the Medical Profession towards Religion, and some of the difficulties which are found in the observance of that duty" and he admits that all he can do is "lay down principles and maxims, which you must apply for yourselves, and which in some respects or cases you may feel have no true application at all" (506). Newman recognizes that, "Every professional man has rightly a zeal for his profession .... [a]nd that zeal soon becomes exclusive, or rather necessarily involves a sort of exclusiveness" (507). There is a rivalry among the professions, with each trying to subordinate all the others and usurp their powers; some even intrude into the province of Religion. And the medical profession has its "special danger, viewed in relation to Catholicity":

Its province is the physical nature of man, and its object is the preservation of that physical nature in its proper state, and its restoration when it has lost it. It limits itself, by its very profession, to the health of the body; it ascertains the conditions of that health; it analyzes the causes of its internuption or failure; it seeks about for the means of cure. But, after all, bodily health is not the only end of man, and the medical science is not the highest science of which he is the subject. Man has a moral and a religious nanure, as well as a physical. He has a mind and a soul; and the mind and soul have a legitimate sovereignty over the body, and the sciences relating to them have in consequence the precedence of those sciences which relate to the body. And as the soldier must yield to the statesman, when they come into collision with each other, so must the medical man to the priest; not that the medical man may not be enunciating what is absolutely certain, in a medical point of view,... but that his action is suspended in the given case by the interests and duty of a superior science, and he retires not confuted but superseded (508-9). 
At the heart of Newman's argument is a particular philosophical view of human nature: "[W]hat is true in medical science might in all cases be carried out, were man a mere animal or brute without a soul; but since he is a rational, responsible being, a thing may be ever so true in medicine, yet may be unlawful in fact, in consequence of the higher law of morals and religion having come to some different conclusion" (510).

A medical philosopher, who has so simply fixed his intellect on his own science as to have forgotten the existence of any other, will view man, who is the subject of his contemplation, as a being who has little more to do than to be bom, to grow, to eat, to drink, to walk, to reproduce his kind, and to die .... He compares his structure, his organs, his functions, with those of other animals .... His practice, then, is according to his facts and his theory. Such a person will think himself free to give advice, and to insist upon rules, which are quite insufferable to any religious mind, and simply antagonistic to faith and morals .... I have known in England the most detestable advice given to young persons by eminent physicians, in consequence of this contracted view of man and his destinies. God forbid that I should measure the professional habit of Catholics by the rule of practice of those who were not! (512-3.)

Newman advises the medical students to look to the Church:

"Gentlemen, if you feel, as you must feel, the whisper of a law of moral truth within you, and the impulse to believe, be sure there is nothing whatever on earth which can be the sufficient champion of these sovereign authorities of your soul, which can vindicate and preserve them to you, and make you loyal to them, but the Catholic Church" (515-6).

And after offering a short defense of the Catholic Church as "the undaunted and the only defender" of the most important spiritual truths, Newman tells us that he has now explained "why it has been so highly expedient and desirable in a country like this to bring the Faculty of Medicine under the shadow of the Catholic Church" (518).

Similar views were articulated by Newman in an article in Weekly Register, where he wrote:

Did the new Catholic University aim at nothing more than the establishment in the metropolis of Ireland of a School of Medicine, presided over by men who profess the Catholic religion and reverence its tenets, it would have proposed to itself an end sufficient to excite a powerful interest in its behalf among the Catholics of other lands .... There cannot be a worse calamity to a Catholic people, than to have its medical attendants alien or hostile to Christianity; there cannot be a greater blessing, than when they are intelligent Catholics, who acknowledge the claims of religious duty, and the subordination and limits of their own functions .... The Catholic University is providing for Catholic students an authoritative school and a safe home, where they may profess their religion without hesitation, practise it without shame, and carry its august decisions into the teaching of the lecture-room and the hospital. $^{2}$

\section{II}

While respectfully acknowledging Newman's right to regard himself as, above all else, a "witness for the faith," we should not feel obliged to think of Newman's views on Christianity and medical science as based exclusively upon 
the kind of metaphysical or theological "perspective" that by its very nature is beyond criticism. I suggest that there are at least four aspects of Newman's analysis that should trouble the reflective moralist and educational theorist.

A. Newman sets up the problem in a curious way. He tells his audience that he is interested in the exact relation in which the medical profession stands towards Catholic education and Catholicism; but he immediately identifies this task with that of determining the principal duty of the medical profession towards religion. It is by no means obvious that the burden of establishing healthy relations between the Church and the medical profession rests almost exclusively on the shoulders of physicians. While he pays lip service to the "autonomy" of science and medicine, Newman never describes in detail the duties of the Church towards the medical profession and, in arguing that theological science is higher than or superior to medical science, he is actually suggesting that the Church may have no duties towards the medical profession at all. Again, Newman does not always seem to appreciate the broader context in which disagreements between physicians and clergymen take place. Newman focuses his attention on only two parties, the physician (or the "medical profession") and the priest (or the Church). But when physicians and clergymen disagree in a particular situation, many parties are involved: the physicians who are directly involved; other members of the medical profession who are indirectly involved; the clergymen who are directly involved; other clergymen in their church (who may or may not agree with the judgments of the clergymen directly involved); the patients directly involved (who ought to have something to say about what is going to be done to them); political leaders (who determine the shape of the relevant civil laws); clergymen of other faiths (whose judgment is especially important when the physician and the patient do not share a common religious faith); and all other members of the political community (who, as potential patients, are indirectly affected by the decisions in question).

Let us consider an example. $\mathrm{X}$ has terminal cancer and is in extreme pain. $\mathrm{He}$ is a loyal Catholic but not as devout a Catholic as his Physician, Y. X has asked $Y$ to put him out of his misery. Newman has given $Y$ clear, simple advice: "Look to the Church." And so $Y$ has consulted with his parish priest and some friends and co-workers in the clergy, most of whom have emphasized the Church's firm stand against euthanasia. Yet $Y$ is still troubled. First, some young Catholic intellectuals have told him that the Church's teaching on the relevant moral issues is actually "rather complex" and "in a state of transition," while several fellow physicians, decent non-Catholics, have suggested to him that perhaps euthanasia is not the key issue here at all. The patient is becoming more and more resentful of what he perceives as the "callousness" of "dogmatic" and "interfering" priests. The deterioration of X's health and spirits is proving to be emotionally costly to his loved ones and financially costly to them and to the community. $\mathrm{Y}$ is haunted by the possibility that he is failing to fulfil his obligations as a professional person in a religiously pluralistic society. He has taken the trouble to examine relevant documents, such as Pius XII's statement on the prolongation of life, and he now finds himself increasingly confused. He wonders whether most of his friends and co-workers in the priesthood are truly in a position to appreciate the intricate details of the particular situation in which he finds himself. Newman has admitted in his address that all he has done is to lay down principles and maxims which in some 
respects or cases the individual physician may feel have no true application at all. But Newman does not seem to realize the extent to which his analysis of physician-priest relations has ignored or at least undervalued such things as the wishes of the patient, theological disagreements within the Church, the civic responsibility of the physician, and so forth. By setting out the problem in the way that he has, Newman has made it appear rather simpler than it is.

B. Newman's portraits of the physician and medical science are themselves caricatures. It is something of an overstatement to say that the medical profession's province is simply the physical nature of man. Newman sees medicine as resting on crudely materialistic assumptions; in his view, the nonreligious (perhaps even non-Catholic) physician must look upon patients as irrational, irresponsible lumps of matter. Newman, of course, lived at a time when psychiatry was not nearly as advanced as it is today; but he is a poor student of the history of medicine if he believes that physicians have traditionally ignored human personality and its relation to physical disease. Moreover, a physician does not have to believe in the existence of a substantial soul (or mind) in order to recognize that there is more to human life than growing, eating, walking, reproducing, and dying.

Yet, while he is critical of the supposed materialism of non-Catholic medical people, he in one sense indirectly encourages medical students to become amoral technicians. Newman rightly believes that a physician ought to be moral, but he identifies the physician's morality with a willingness to accede to the demands of certain religious authorities. Newman is discouraging future physicians from making use of their faculty of moral judgment; he is saying, in effect, that a physician who is doing his job properly will not make any independent value-judgments but will leave it to Roman Catholic clergymen to make the basic value-judgments for him. For Newman, the reflective physician who weighs moral arguments is potentially a dangerous person who may well end up usurping the powers of priests and giving detestable advice to young people. Yet, even if Newman is right in believing that Catholic morality is the soundest possible morality, which is at least challengeable, he cannot afford to ignore the fact that there are certain situations, medical emergencies, in which it is necessary for the physician to moralize on his own. Being moral requires more than willingness to accede to the demands of religious authorities; it also requires skills in moral reasoning. Newman's ideal physician, then, is on one level really more amoral than moral.

Newman believes that the physician lacks the moral knowledge of the priest, a knowledge that is largely acquired by means of a scientific activity roughly comparable to (but higher than) the medical person's physical science. Newman is clearly emphasizing dogmatic ethics at the expense of both philosophical ethics and the "moral sense" to which he normally attaches great importance (as in his Grammar of Assent).

C. Newman has set up a series of hierarchies: "the mind and soul have a legitimate sovereignty over the body, and the sciences relating to them have in consequence the precedence of those sciences which relate to the body"; "the medical man [must yield] to the priest"; the "law of morals and religion" is "higher" than medical truth. Many of us agree with Newman that in some sense spiritual things are more important than physical or material things, though fewer of us share Newman's particular metaphysical and theological 
conception of the spiritual. But even many Christians now believe that Christian philosophers and theologians have traditionally undervalued the importance of the body and physical things. For many centuries, Catholic leaders encouraged certain ascetic practices which involve mutilation of the body; most contemporary Catholics find references to such practices rather embarrassing. Catholics and non-Catholics alike now tend to look negatively on the Inquisition's practice of torturing and murdering for the purpose of "saving souls." Because human bodies are important, the physician, having been entrusted with the care of human bodies, has a special obligation to question the judgment of Inquisitors, military officers, and others who hold that the mutilation or destruction of human bodies is necessary or appropriate for "spiritual" reasons. There is much to be said for a system of "checks and balances" so, for example, the priest can check the influence of mentally unbalanced clergymen. Certainly Newman himself recognized that the Catholic Church, like other institutions, has had its share of mentally unstable functionaries for, as so many of Newman's biographers have suggested, it was Newman's misfortune to come frequently into conflict with such people.

Moreover, while a pious person worries more about her soul than her body, she also recognizes that she has a moral and religious obligation to look after her body. When a devout but sophisticated modern Catholic requires the services of a surgeon, she normally seeks out the best available surgeon, who may or may not be a Catholic. (Most of us know the right answer to Socrates's famous question to Polemarchus: "Is it the just man, then, who is a good and useful associate and partner in the placing of draughts or the draughts player?"') ${ }^{3}$ Newman, however, is not clear on this point. While on one level indirectly encouraging physicians to be amoral technicians, he suggests in other lines that he might encourage ill Catholics to go to modestly competent Catholic surgeons rather than highly competent non-Catholic surgeons. And when Andrew Ellis, dean of the Catholic University's medical faculty, suggested to Newman that it would be helpful to have a few competent Protestants on the faculty, Newman gave him a straightforward reply: "A Catholic University cannot by any possibility appoint Protestant Professors." 4

We must also question Newman's description of the hierarchy of the sciences. Newman wants to rank sciences according to the importance of their subject-matter; other descriptions of the hierarchy of the sciences (such as those of Aristotle and Comte) have not involved so much value-judgment. It is worth noting that for Aristotle, medicine and moral knowledge are both "inferior" to pure science, which is knowledge of the "necessary and etemal" rather than knowledge of what lies in the realm of possibility. (For Aristotle, medicine is not a science but a kind of techne. ${ }^{5}$ ) Newman fails to distinguish adequately between dogmatic ethics and pure theology. Of greater importance, he fails to recognize that not all theological subjects are more important than all medical subjects. Knowledge of some minor ritual can hardly be regarded as more important than knowledge of how to save the archbishop's life. (More than one medieval pope preferred to be closer to his Jewish physician than to the clever theologians from Paris.)

Newman is also careless in suggesting that a thing may be true in medicine yet unlawful in fact. What he wants to say, of course, is that a thing may appear right from the perspective of the physician and yet be wrong. 
D. Gerald Vann has observed that "the subordination of practical science in general to religion, axiomatic in the Middle Ages, had by the time of the Reformation to some extent ceased to be acknowledged in practice; thereafter the split widened and came eventually to be justified in theory."6 Newman himself tends to look back to the Middle Ages with nostalgia. He chooses to ignore or undervalue, among other things, the medieval Church's checkered track record in its dealings with liberal scientists and intellectuals. Students of intellectual history can make a strong case for the position that it is never expedient or desirable to bring scientific faculties under the "shadow" of an ecclesiastical institution.

We realize how myopic Newman could be when we consider that he delivered his address on "Christianity and Medical Science" shortly after the establishment in England of the Royal Commission of 1850, which came into being largely as the result of the movement for the abolition of the hated "religious tests" for admission to Oxford and Cambridge. Charles Newman has made the plausible suggestion that religious tests were scrapped at least partly because Oxbridge professors feared that their medical departments would be "shown up" by rival institutions with a more liberal admissions policy. So Newman was advocating bringing the medical faculty under the shadow of the Church at a time when his Anglican counterparts were especially sensitive to the dangers of doing so. ${ }^{7}$

\section{III}

There are aspects of Newman's analysis that merit a more respectful hearing. Newman is right when he says that there is a rivalry among the professions, with each trying to subordinate the others and usurp some of their powers; and he understands well that there is a "special danger" for the medical profession. The physician is a great authority figure in our society, as he was in Newman's, and often he comes to believe that he has access to some special moral insight that is not available to other educated people. In point of fact, the typical physician has no more (and no less) moral insight than the typical musician, or economist, or chemist. The principal reason for this is quite simple: he has had no more (and no less) moral education than any of these people, and he has not spent a remarkable amount of time and effort reflecting on basic ethical questions. However, a large part of the training of a clergyman is, as a matter of fact, ordinarily devoted to advanced moral education--or at least semi-philosophical discussion of basic ethical problems--so that even if the typical clergyman does not possess supernatural moral insight, he is often in a position to give relatively profound advice on moral subjects to other people, including physicians.

Newman rightly recognizes the need for institutions where Roman Catholics "may profess their religion without hesitation, practise it without shame, and carry its august decisions into the teaching of the lecture-room and the hospital." Newman lived most of his life in a society in which open anti-Catholic discrimination was sanctioned by some of the most influential people, including those who controlled the major universities. Even in our society, however, believing Catholics at pseudo-liberal institutions of higher leaming are often made to feel uncomfortable and insidiously encouraged to become "less Catholic." For this reason, and others, Catholic universities (and other denominational universities) represent an important alternative to their 
secularist, non-denominational counterparts. Moreover, Catholic morality is distinctive, and even some of its most severe critics will admit grudgingly that in certain ways it is loftier than the "conventional" morality. That commitment to Catholicism brings with it the acceptance of certain principles of medical ethics goes without saying. For the record, however, I will cite a few statements from a popular Catholic ethics text:

- For the surgeon or doctor to kill a human being voluntarily is to work in contradiction to the end of the work of medical practice. This is always immoral. Neither abortion nor mercy-killing (euthanasia) can be justified morally. ${ }^{8}$

- The use of psychological and psychoanalytical treatment is not at all immoral. However, to reduce all the causes of mental disturbance to sex frustration (as in the popular conception of psychoanalysis) is unreasonable. ${ }^{9}$

- A person who resists treatment because he is temporarily "out of his mind," may be forced to take reasonable treatment for his own good. Relatives and guardians should be consulted, in the case of children of permanently insane people. ${ }^{10}$

Newman believes that medical education and medical practice can never be value-neutral; and though the opposite view has sometimes been defended, I am inclined to agree with Newman on this point. Also, while Newman has been careless in dismissing most non-Catholic physicians as shallow materialists, we must recognize that many physicians are materialists, and as such, have as distinctive a metaphysical outlook as committed Catholic physicians.

We may view Newman's position from another perspective. NonCatholics cannot reasonably be expected to agree with Newman that the Catholic Church is "the undaunted and the only defender" of the highest spiritual truths. We must remember, however, that Newman is addressing himself primarily to Catholic medical students. A physician who professes to be a Catholic ought to take the advice of popes, bishops, and priests very seriously. Many contemporary Catholic physicians (and Catholic lawyers, businessmen, and so forth) do not appear to recognize their obligation to do so. Newman overstates the relevant point when he insists that the medical person must yield to the priest. But a person who calls himself a Catholic while having little or no interest in Catholic teaching is a hypocrite or, at very least, a self-deceiver.

Newman's talk of the "duty of the Medical Profession towards Religion" sounds less strange when we remember that Newman never lived in a society in which there was the degree of separation of church and state that most of us now take for granted. Newman would not have understood or looked favorably upon the kind of church-state separation that characterizes modem Canadian or American society. It is relatively easy for most North American physicians to feel that they have no obligation to an ecclesiastical institution, or to religion in general, comparable to their obligation to the state that has licensed them to practise medicine. But reflecting on this fact, we should also be reminded that in North American societyhb, the churches are not wholly "separate" from the state and are in many important ways actually subordinate to it. While the North American kind of church-state "separation" is in some ways the least of various possible evils, we must also recognize that secular leaders are nowadays, on the 
whole, no more just or compassionate than religious leaders, and perhaps somewhat less so. I suspect that in years to come, North Americans will become increasingly critical of medicine under the "shadow" of the state and increasingly sympathetic to the attempts of churchmen and other clergymen to bring religious values back into medical education and medical practice.

In our own society in recent years, the medical profession has become more and more appreciative of the value of consulting with academic moralists and drawing on the wisdom of these humanists. More and more hospitals seek their advice, and more and more medical schools encourage--or even require-their students to take instruction from them. By showing a healthy respect for the value of reflective moralists in hospitals and medical schools, medical leaders go a long way towards following Newman's counsel. But even if a reborn Newman would be generous today in his appraisal of Protestant and Jewish moralists, it is unlikely that he would think much of atheistic humanists who are accepted in medical circles as proponents of a "purely philosophical or rational" and religion-free moral expertise. The author of The Idea of a University is so often remembered for his defense of liberal education that we sometimes lose sight of the fact that he was, above all else, concerned with affirming the centrality of religion to education--professional as well as liberal. Now, even if Newman was a religious bigot, he still may have been right in claiming that the religious moralist can offer his students something very much superior to what any secular moralist can. That is a thesis that I am not prepared to consider here, but I will grant that it is worthy of serious consideration and that few writers have advanced it more earnestly than Newman has.

\section{Notes}

'John Henry Newman, The Idea of a University (London: Longmans, Green, $1901(1852,1858)$, p. 505 . Numbers in the text refer to pages in this work.

2John Henry Newman," The Catholic University," art. 3 (6 February, 1858) in John Henry Newman, Letters and Diaries, ed. Charles Stephen Dessain, XVIII (London: Nelson, 1968), 570-572.

${ }^{3}$ Plato, Republic 333b (trans. by Paul Shorey).

${ }^{4}$ Letter, John Henry Newman to Andrew Ellis (21 July, 1854) in John Henry Newman, Letters and Diaries, ed. Charles Stephen Dessain, XVI (London: Nelson, 1965), 203.

${ }^{5} \mathrm{Cf}$. Aristotle Nicomachean Ethics 1139b-1141b.

${ }^{6}$ Gerald Vann, Moral Dilemmas (London: Collins, 1965), p. 47

${ }^{7}$ Cf. Charles Newman, The Evolution of Medical Education in the Nineteenth Century (London: Oxford University Press, 1957), pp. 113, 276-278.

${ }^{8}$ Vemon J. Bourke, Ethics (New York: Macmillan, 1966), p. 454.

${ }^{9}$ Ibid.

${ }^{10}$ Ibid. 